\title{
EFFECT OF DIFFERENT CONCENTRATIONS OF AQUEOUS Ascophyllum nodosum Extract on Flowering AND FRUITING IN SOME VEGETABLES
}

\author{
1 Aliko, A.A.*, ${ }^{2}$ Manga A.A., ${ }^{1}$ Haruna, H. and ${ }^{3}$ Abubakar, A.W. \\ ${ }^{1}$ Department of Plant Biology, Bayero University, P.M.B. 3011, Kano - Nigeria. \\ ${ }^{2}$ Department of Agronomy, Bayero University, P.M.B. 3011, Kano - Nigeria. \\ ${ }^{3}$ Department of Biological Sciences, Federal University, Dutse - Nigeria \\ * correspondence author: aaaliko.bio@buk.edu.ng (08064980100)
}

\begin{abstract}
A study was conducted in 2013 at the Screen House of Teaching and Research Farm of Faculty of Agriculture, Bayero University, Kano to test the effect of aqueous extract of of Ascophyllum nodosum extract on flowering and fruiting in watermelon (Cowlak) and okra (NHB-AI-13). Treatment consisted of four levels of the extract $(0.5,1.0,1.5$ and $2.0 \mathrm{~g} / \mathrm{L})$ and a control. These were replicated three times. Results obtained on the number of days to flowering in both plants showed significant effect of the extract. Plants treated with 1.5 and $2.0 \mathrm{~g} / \mathrm{L}$ seaweed extract flowered earlier and produced greater number of flowers and subsequently more number of fruits. Average number of flowers were greater in both plants treated with $2.0 \mathrm{~g} / \mathrm{L}$. However, the average number of fruits per plant was observed to be 5.33 and 2.33 in okra and watermelon respectively treated with $2.0 \mathrm{~g} / \mathrm{L}$ which is greater than 2.00 and 0.33 observed in the same plants given $0 \mathrm{~g} / \mathrm{L}$. Replications treated with $0.5,1.0$ and 1.5 also showed greater effect on the onset of flowering, number of flowers as well as the fruit yield when compared with the control treatment.
\end{abstract}

Key words: Watermelon, Okra, Seaweed, flowering, fruiting.

\section{INTRODUCTION}

The discovery of plant hormones and their ability to regulate all aspect of plant growth and development were defining moments in vegetables productions. Their impact on plants has nowhere more vividly chronicled than in tree fruits. However, fruiting vegetables like Okra (Abelmeschus esculentus L.) and water melon (Citrullus lanatus L.) are considered as high value crops, particularly in the Northern region of this country. This is because an ambitious agricultural plan is being carried out in land reclamation in order to expand the dry agricultural area to meet the growing needs of population and export to foreign markets.

Production of these crops has taken a very important place in the field of agriculture. However, in terms of cultivated area, Nigeria and Benin were reported to have least production of these vegetables while South Africa is ranked to have the highest production rate. Poor flowering and fruit development, abscission, poor growth, pest and diseases are among other factors affecting production of fruiting vegetables in Nigeria. Inconsistent flowering and fruiting is considered by many to be the most important physiological response regulated by plant bioregulators. Regulation of flowering and fruiting can be seen to attract the attention of plant physiologists into research with many visions. Some investigates into the effect of some foliar application of synthetic hormones on the growth and yield while some into special fertilization program. Application of synthetic growth promoters like auxins such as fenoprop (2[2,4,5-trichlorophenoxy] propionic acid) and gibberellins were very common and effective some decades ago, but very much expensive, not within the reach of Nigerian local farmers and there is also fear of being contacted with carcinogenic dioxine by the animals which might feed on the treated plants. Research conducted by Tomlin (2006) who tested NAA on rats via oral ingestion at $1000-5900 \mathrm{mg} / \mathrm{kg}$ reported that the NAA has induced cancer. However, these created the development of some viewpoints opposing the use of many synthetic hormones with regards to other human health issues especially when production is export-oriented. These among the other reasons made the registration of some of these synthetic hormones to drop.

Liquid extract of seaweed, a loose colloquial term encompassing macroscopic, multicellular, benthic marine algae have gained importance as foliar sprays for several crops (Hong et al., 2007; Adams-phillips et al., 2004; Akula et al., 2000). This is because the extract was reported by Challen and Hemingway (1965) to contains growth promoting hormones IAA, IBA, Cytokinins, trace elements ( $\mathrm{Fe}, \mathrm{Cu}, \mathrm{Zn}, \mathrm{Co}, \mathrm{Mo}$, $\mathrm{Mn}, \mathrm{Ni})$, vitamins and amino acids. Rama (1991) reported that asqueous extract of Sargassum wightii when applied as a foliar spray on Zizyphus mauritiana showed an increased yield and quality of fruits. Tomato shoot and root growth were also improved by applying seaweed extract either as foliar or soil application (Zodape et al., 2011).

In line with these studies and due to the fact that florigen which is the hypothesized hormone-like molecule responsible for regulating flowering in plants is produced in the leaves and act in the shoot apical meristem of buds and growing tips, it is important to assess the seaweed flowering and fruiting control and thus, the purpose of this study is to find out the effect of different concentrations of seaweed extract on flowering and fruiting. 
Bajopas Volume 10 Number 1 June, 2017

MATERIALS AND METHODS

The research was conducted at the ScreenHouse of Teaching and Research Farm of Faculty of Agriculture, Bayero University, Kano located in the Sudan Savannah agro ecological zone of Nigeria (Latitude $11^{\circ} 58^{\prime} \mathrm{N}$, Longitude $8^{\circ} 25^{\prime} \mathrm{E}$, and altitude $458 \mathrm{~m}$ ) in 2013 dry season. $7 \mathrm{~kg}$ of top soil and compound fertilizer (N.P.K. 15-15-15) at the rate of $0.58 \mathrm{~g} \mathrm{pot}^{-1}$ were mixed and put into planting pots of $23 \mathrm{~cm}$ diameter and $17 \mathrm{~cm}$ depth. The mixture was then watered for two days to allow adequate saturation as recommended by the nursery operations standard (Kano State Ministry of Environment, 2005). Planting was then followed and the plants were routinely managed by daily watering, weeding, pest control and other agronomical practices. Treatments were formulated by soaking $10 \mathrm{~g}$ of fresh grounded material of seaweed with $1 \mathrm{~L}$ of distilled water and filtered out. The filtrate obtained was diluted into the following concentrations:

$1 \mathrm{~L}$ of filtrate into $20 \mathrm{~L}$ of water to obtain $0.5 \mathrm{~g} / \mathrm{L}$

$1 \mathrm{~L}$ of filtrate into $10 \mathrm{~L}$ of water to obtain $1.0 \mathrm{~g} / \mathrm{L}$

$1 \mathrm{~L}$ of filtrate into $6.7 \mathrm{~L}$ of water to obtain $1.5 \mathrm{~g} / \mathrm{L}$

$1 \mathrm{~L}$ of filtrate into $5 \mathrm{~L}$ of water to obtain $2.0 \mathrm{~g} / \mathrm{L}$

Distilled water as a control

Each treatment was replicated three times making 30 experimental units and these were laid in Complete Randomized Design. The treatments were applied by foliar spray using CP 20 Knapsack sprayer at 2, 4 and 6 weeks after germination.

Measurements on number of days to first flower initiation, number of days to $50 \%$ flowering, number of flowers per plant, number of aborted flowers and number of flowers fertilized were recorded as flowering parameters while number fruits per plant, fruit weight, fruit length/diameter and fruit yield per hectare as fruiting parameters.

\section{RESULTS AND DISCUSSION}

Number of days to first flower initiation and $50 \%$ flowering in both plants was significantly $(P<0.05)$ affected by aqueous extract of Ascophillum nodosum. Plants treated with 2.0 and $1.5 \mathrm{~g} / \mathrm{L}$ flowered within few days while flowering was delayed in plants treated with 0.5 and $1.0 \mathrm{~g} / \mathrm{L}$ as well as in control experiments. This is indicating that extract of Ascophillum nodosum was absorbed by the plant and influenced its flowering time. Similar trend was also observed with regards to number of flower per plant and thus the extract could be said to have supplemented the need of the plant leaves to start manufacturing flowering hormone which mostly occur when the light goes down to 12 hours or less (Turck et al., 2008). Nigerian Sudano-sahelian savannah experiences long shorter night in a year (Dugje et al., 2012). Flowering is greatly affected in the region and normally starts very late (September to December). Therefore, the effect that seaweed extract has shortened the photoperiod prerequisite of the plants.

Fruiting which is the end of the reproductive cycle of flowering plants was regulated by foliar spray of aqueous seaweed extract because there was significant difference in fruit number per plant with replications sprayed with $2.0,1.5$ and $1.0 \mathrm{~g} / \mathrm{L}$ seaweed extract recorded greater number of fruits in okra when compared to what was obtained in 0 and $0.5 \mathrm{~g} / \mathrm{L}$. This development could be linked to the effect the extract has on flowering and inhibition of premature fruits drop, even though no significant difference was detected with regards to number of fruits dropped.

The importance of seaweed has been documented for several decades. Besides their application as farmyard manure, liquid extracts obtained from seaweeds have gained importance as foliar sprays for several crops (Sivasankari et al., 2006; Norrie et al., 2002). This is because the extract contains growth promoting hormones IAA, IBA, cytokinins, trace elements ( $\mathrm{Fe}, \mathrm{Cu}, \mathrm{Zn}, \mathrm{Co}, \mathrm{Mo}, \mathrm{Mn}, \mathrm{Ni})$, vitamins and amino acids (Challen and Hemingway, 1965). The result of this study is in agreement to previous findings where all flowering parameters and number of fruit were observed to be enhanced up to $80 \%$ by the application of the seaweed extract. The enhanced flowering and fruiting effects by seaweed could be affected by florigen, gibberellins and cytokinins which are present and potentially involved in enhancing plant flowering and fruiting. Therefore, the improvement of flowering and fruiting may possibly be the result of the hormonal activity of the seaweed extract.

Table 1: Effect of different concentrations of Ascophillum nodosum aqueous extract on flowering in watermelon and okra

\begin{tabular}{|c|c|c|c|c|c|}
\hline \multicolumn{6}{|c|}{ WATERMELON } \\
\hline $\begin{array}{c}\text { Extract } \\
\text { concentrations } \\
(\mathrm{g} / \mathrm{L})\end{array}$ & $\begin{array}{l}\text { Number of } \\
\text { days to } 1^{\text {st }} \\
\text { flower } \\
\text { initiation }\end{array}$ & $\begin{array}{c}\text { Number of } \\
\text { days to } 50 \% \\
\text { flowering }\end{array}$ & $\begin{array}{c}\text { Number of } \\
\text { flower per } \\
\text { plants }\end{array}$ & $\begin{array}{l}\text { Number of } \\
\text { droped } \\
\text { flowers per } \\
\text { plants }\end{array}$ & $\begin{array}{c}\text { Number of } \\
\text { fertilized } \\
\text { flower per } \\
\text { plants }\end{array}$ \\
\hline 0.0 & 29.33 & 35.33 & 1.67 & 0.67 & 1.00 \\
\hline 0.5 & 25.67 & 34.33 & 1.67 & 0.33 & 1.33 \\
\hline 1.0 & 26.67 & 31.67 & 2.67 & 1.33 & 1.33 \\
\hline 1.5 & 23.33 & 29.00 & 3.33 & 1.33 & 2.00 \\
\hline 2.0 & 20.00 & 26.33 & 3.67 & 1.00 & 2.67 \\
\hline LSD $(0.05)$ & 3.61 & 4.24 & 1.01 & NS & 0.78 \\
\hline \multicolumn{6}{|c|}{ OKRA } \\
\hline 0.0 & 41.67 & 47.33 & 5.33 & 2.33 & 2.00 \\
\hline 0.5 & 39.67 & 45.00 & 5.67 & 1.33 & 3.33 \\
\hline 1.0 & 39.00 & 43.00 & 7.00 & 1.67 & 5.00 \\
\hline 1.5 & 31.00 & 35.00 & 8.00 & 1.33 & 6.00 \\
\hline 2.0 & 30.00 & 35.33 & 8.00 & 1.33 & 6.33 \\
\hline LSD $(0.05)$ & 5.46 & 4.67 & 1.50 & NS & 1.86 \\
\hline
\end{tabular}


Bajopas Volume 10 Number 1 June, 2017

Table 2: Effect of different concentrations of Ascophillum nodosum aqueous extract on fruiting in watermelon and okra

\begin{tabular}{cccc}
\hline \multicolumn{4}{c}{ WATERMELON } \\
\hline $\begin{array}{c}\text { Extract concentrations } \\
(\mathbf{g} / \mathbf{L})\end{array}$ & Number of fruits & $\begin{array}{c}\text { Fruit diameter/length } \\
\mathbf{( c m})\end{array}$ & Fruit weight (g) \\
\hline 0.0 & 0.33 & 16.30 & 72.80 \\
0.5 & 1.33 & 16.47 & 82.63 \\
1.0 & 1.00 & 16.13 & 87.13 \\
1.5 & 1.67 & 17.33 & 88.13 \\
2.0 & 2.33 & 18.40 & 86.43 \\
LSD(0.05) & 0.90 & $\mathrm{NS}$ & $\mathrm{NS}$ \\
\hline 0.0 & & & 12.40 \\
0.5 & 2.00 & 11.47 & 12.98 \\
1.0 & 3.33 & 11.97 & 14.83 \\
1.5 & 5.00 & 13.00 & 15.23 \\
2.0 & 6.00 & 12.80 & 13.35 \\
\hline LSD $(0.05)$ & 6.33 & 12.30 & $\mathrm{NS}$ \\
\hline
\end{tabular}

\section{CONCLUSION}

The study has indicated that 1.5 and $2.0 \mathrm{~g} / \mathrm{L}$ aqueous extract of seaweed (Ascophyllum nodosum) enhanced plant flowering, particularly number of days to flower initiation and $50 \%$ flowering. For fruiting, 2.0, 1.5 and $1.0 \mathrm{~g} / \mathrm{L}$ seaweed extract recorded greater number of fruits in okra when compared to what was obtained in 0 and $0.5 \mathrm{~g} / \mathrm{L}$ under screen house condition Therefore,

\section{REFERENCES}

Adams-Phillips, L., Barry, C., Giovannoni, J. (2004). Signal transduction systems regulating fruit ripening. Trends Plant Science 9:331-338

Akula, A., Akula, C., Bateson, M. (2000). Botaine: a novel candidate for rapid induction of somatic embryogenesis in tea (Camellia sinensis [L.] O. Kuntze). Plant Growth Regul 30:241:246

Challen, S.B., Hemingway, J.C. (1965). Growth of higher plants in response to feeding with seaweed extracts. Proc. 5th Ind. Seaweed Symp.

Dugje, I.Y., Teli, I.A., Larbi, A., Gyamfi, I., Buah, S.S.J., Kanton, R.A.L., Kombiok, J.M., Kamara, A.Y. and Hoeschle-Zeledon, I. (2012). Report of community analyses for sustainable intensification of cereal-based farming system in sudano-sahelian zone in Ghana. International Institute of Tropical Agriculture (IITA) Pp 1-130.

Hong, D.D., Hien, H.M., Son, P.N. (2007). Seaweeds from Vietnam used for functional food, medicine and biofertilizer. Journal of Applied Phycology 19:817 - 826. foliar spray of 1.5 and $2.0 \mathrm{~g} / \mathrm{L}$ Ascophillum nodosum extract on watermelon and okra is a potential and environmental responsive methodology to improve onset and $50 \%$ flowering as well as number of flowers and fruits in okra and watermelon. Based on the result of this preliminary work, the seaweed plant contains growth promoting compound.

Kano State Ministry of environment, (2005). Nursery tending operations and establishment. A seminar paper presented at forestry department. Pp. 1-12

Norrie, J., Branson, T., Keathley, P.E. (2002). Marine plants extracts impact on grape yield and quality. Acta Hort. (ISHS), 594: 315-319.

Rama, Rao, K., (1991). Effect of seaweed extract on Zizyphus mauratiana Lamk. Journal of Indian Botanical Society 71: 19-21.

Sivasankari, S., Venkatesalu, V., Anantharaj, M., Chandrasekaran, M. (2006). Effect of seaweed extracts on the growth and biochemical constituents of Vigna sinensis. Bioresource Technology 97: 1745-1751.

Tomlin, C.D.S. (2006). The pesticide manual, $14^{\text {th }}$ edition, UK

Turck, F., Fornara, F., Coupland, G. (2008). Regulation and identity of florigen: Flowering locus T moves centre stage. Annual Review of Plant Biology 59:573-594.

Zodape, S.T., Gupta, A., Bhandari, S.C., Rawat, S.C., Chaudhary, D.R., Eswaran, K., Chikara, J. (2011). Foliar application of seaweed sap as biostimulant for enhancement of yield and quality of tomato (Lycopersicon esculentus Mill.). Journal of Science and Industrial Research 70(3):215-219 